\title{
Representation of Social Realities of Latin America in Marquez's Literary Discourse
}

\author{
Mohammad B. Aghaei \\ Department of English, Islamic Azad University, Tabriz Branch, Tabriz, Iran \\ E-mail: aghaeimb@yahoo.com
}

Doi:10.7575/aiac.alls.v.6n.1p.55

URL: http://dx.doi.org/10.7575/aiac.alls.v.6n.1p.55
Received: $15 / 09 / 2014$

Accepted: 18/11/2014

\begin{abstract}
Gabriel Garcia Marquez is always keen on presenting to the people the various facets of their history. His literary language acts as effective means for describing the critical historical aspects of Latin America because the legacy of colonialism had destroyed so many important traces of the native culture of that area. This has led him to search for his identity by looking at various periods, before and after colonization. Because of this, the historical and cultural issues were his main thematic subject matters; such as savagely fought wars of independence, bloody conflict between the political parties, massacre of banana workers, deplorable effects of Hispanic culture on the community.
\end{abstract}

Keywords: colonialism, plagues, cultural values, power of love, skeptical rationalism.

\section{Introduction}

Marquez's literary discourse actually creates a microcosm of Latin America, portraying the essence of the continent with all its aspects such as ethnicity, social norms and conventions, economic problems, destructive domination of colonial and imperialistic powers and civil wars that led to a series of insecurities and poverty in the community. In fact, whatever he has presented in his works is related to the realities of the continent that have been portrayed in his fictional world. In his works, every single line is a reference to the socio-cultural aspects and a certain critical point in the history of this continent and provides a magnifying glass for the reader to clearly conceptualize them. Hence, the past, the present and sometimes the future are almost merged in his literary discourse and its interpretation is of paramount importance for acquiring a vivid and multifaceted picture of the continent. In this article, the intention is to probe into Marquez's artistic imagination giving a general perspective on the historical and cultural aspects and the social realities of Latin America, particularly of Colombia.

The significant success achieved by Marquez was in 1967 with the publication of his masterpiece One Hundred Years of Solitude. This novel is perhaps his best-known contribution in awakening interest in Latin American literature. It actually depicts Latin America with all its aspects. Regina Janes asserts that the total novel treats Latin America socially, historically, politically, mythically, and epically, that is at once accessible and intricate, lifelike and selfconsciously, self-referentially fictive (Janes 1981: 7). Generally, the novel represents the history of the countries of the continent where their inhabitants witnessed 'interminable civil wars, dictators, coups d'etat., brief resurgences of democratic rule, social revolutions promising much and betrayed by the makers of revolution or aborted by the prompt arrival of the U.S. Marines or of CIA funds to finance the counterrevolution" (ibid.: 3). On the other hand, in the sixteenth century, the continent had experienced the domination of Spain's colonialism and then it came into contact with a series of native Indians and black slaves. Later, it was faced with a set of post independence wars, and in the early of twentieth century, the Americans came and brought modern Western imperialism. Therefore, the history of Latin America comprises of a set of events that have repetitiously occurred in different forms during different periods, starting from colonialism to recent imperialism. On a historical level, the novel can be seen as a representation of Colombian history, Latin American history, or even human history.

\section{Lack of a Stabilized Government}

The novel One Hundred Years of Solitude portrays the historical realities of Latin America through a complex family relationship and critical events occurring within the story. In an interview with Dryfus, Marquez says that "it [One Hundred Years of Solitude] is more or less, based on historical reality. The reasons, the motives and manner in which the events...occurred were exactly as in novel" (Dryfus 1983b: 116). The novel basically implies the development and annihilation of Latin America; Latin America that once had a developing population of native Aztecs and Incas, but, slowly, as the European explorers arrived, bringing to them new technology and capitalism, and consequently the native population had to adjust themselves to a modern condition. This is the main factor that took away the people from their own identity and values. In the story, the inhabitants begin to exchange their traditional way of life for a modern one, hoping that this new condition would lead them to a better and more comfortable life. But they were unaware that behind this modern life lay their annihilation. The arrival of the foreign banana company was actually the starting point of the annihilation of Macondo and its inhabitants. In addition to signifying the early stage of Latin America's 
development, the novel also depicts the current political status of various Latin American countries. Various dictatorships came into power in these countries as in Nicaragua, Panama and Cuba, but none of them managed to establish a stable government; on the contrary, these resulted in politically chaos. Analogously, although Macondo undergoes constant changes such as frequent developments and government changes, it is unable to establish a stable and well-organized government and a peaceful society.

Another theme that is manifest in the novel is incest. From the very beginning, incest is a threat to the Buendia family. In fact, the majority of the members of Buendia family have incestuous relationships except Ursual, Jose Arcadio Buendia's wife. She is anxious about the incestuous relationships among the family members. Marquez deals with all aspects of the life of the Buendia family in a very honest and realistic manner, even their sexual life is no exception. For instance, Aureliano Buendia falls in love with the nine year old Remedios at first sight. It is fairly obvious that he does not have the desire of a typical man. In any culture, marriage with a nine year old girl is completely unacceptable and contrary to the social and moral principles. However, his marriage with her is considered a normal affair within the Buendia family.

Another aspect is the sexuality of the female characters. Generally, the female characters who have unconventional relationships are Rebeca, Petra Cotes, Amaranta Ursula. They are actually happier and more sympathetic than other female characters considering the moral standards of society, like Amaranta and Fernanda del Carpio. In the novel, it is indicated that Aureliano Segundo's affairs with Peta Cotes cause the proliferation of animals. It implies that free love is easily considered a healthy norm within the community. Many sexual affairs are outlived in the novel. Probably, the reason is that sex was a means for both male and female characters to overcome their solitude. Two rapes occur in the novel as well; Jose Arcadio Buendia rapes his bride, Ursula, and Aureliano rapes Amaranta Ursula. The colonel himself also has numerous affairs, fathering seventeen bastard sons from many women of whom he loses count.

\section{Social Values}

Marquez's literary discourse represents a clear picture of the essence of Colombian culture and society. Chronicle of a Death Foretold is one of his novels that throws light on the social condition of Latin America and on the way the people live. The characters in this novel actually mimic the behavior of people in the real world and they behave according to the social norms that attribute different significance to the realities. Because of these norms, every character is 'partially victimized': Angela Vicario is a victim of the double norms between men and women in the society. After being returned to her family because of her premarital sex with Santiago Nasar, she is beaten by her brothers. Angela's brothers force her to confess the name of her lover, who is then killed in front of people who do nothing to stop the murder. Bayardo San Roman is also a victim of deceit since he marries Angela whom he believes to be a virgin and indeed it is she who deceives him. Being a product of a male-dominated society, he is left with no other option but to return her to her family. Santiago Nasar, around whom the novel's events revolve, is also a victim as his guilt or innocence remains uncertain and unclear till the end of the story.

Marquez's aim is also to manifest all the characters as being equally 'guilty' in Santiago Nasar's death. This is further explicated by the following incidents: Bayardo is guilty because of returning Angela and Vicario brothers are guilty because of murdering Santiago Nasar. On the other hand, Angela is guilty because of her false claim that Santiago Nasar is her lover. Santiago Nasar is also guilty of abusing his servant and his fiancee, Flora Miguel, is guilty as she secretly wishes Vicario brothers to kill him. The mayor is also shown to be guilty as he is engrossed in the game of dominoes till the time for the killing approaches and also the priest who is unduly preoccupied worrying about the Bishop's visit. Finally, the people of the town are also guilty as they are informed right from the start that Vicario brothers are going to kill Santiago, but do nothing to prevent the murder.

Another significant theme of the novel is 'honor'. In Colombian culture, honor is taken very seriously. The main indicator is that nobody in the novel prevents the murder of Santiago Nasar, but instead they condemn him to death for his immoral deed. Honor is believed to be the fundamental moral trait which is vital to keeping society on the path of righteousness. A person without honor is considered an outcast in the community in Latin American society, and virginity also plays a crucial role in upholding a woman's virtue and dignity at the time of her marriage. This sanctity is one of the primary themes in the novel which is based on the understanding that upholding a woman's virginity/chastity is reason enough to kill for and anyone violating this ethic or principle takes the risk of death. Hence, we see that virginity is viewed as the highest level of honor and murder itself is committed in order to regain Angela's honor which she had lost when she had premarital sex. The people of the town believe that they should not interfere in the dispute; that it should be left to the people involved to resolve it. Even the court did not condemn Angela's brothers for murdering Santiago Nasar as it was considered as an honor killing.

Familial duty is another important aspect of Latin American culture. The main responsibility of every Colombian family is to safeguard the girl's chastity before her marriage, even if she doesn't love the man she marries. In the novel, Angela's family fails to perform its responsibility when they force her without her consent to marry Bayardo for his wealth, ignoring her pleas not to marry him. Bayardo, on his part, is smitten by Angela the moment he lays eyes on her. On the other hand, he ignores the social norms that require him to meet Angela and ask for her consent for marriage. In fact, he tries to entice her family with his wealth and money before directly courting her. It appears as if he is attempting to purchase her happiness by his immeasurable fortune. He is, in fact, a widower, who, after the death of his wife, had many illicit relationships with various types of women; a fact to which Angela and her family remain oblivious. 
An important part of Chronicle of a Death Foretold is its emphasis on 'male pride', especially on the sexual behavior of the male characters. In the novel, Marquez gives a clear picture of the dominant social rules and norms. The society was primarily a male-dominant one; the men and women were not equal according to the social rules; women were considered as middle class and the men believed themselves to be free to do anything. Colombian culture gave men the right to go to a brothel or after any woman and engage in as many sexual encounters as they liked. Even the men took pride in such actions; they never felt ashamed of it because the society accepted these desires and needs of men. It shows that women were used as objects to satisfy men's desires. This machismo is apparent when Bayardo returned Angela as well as when her brothers got drunk and followed an old traditional norm that emphasized on the keeping of virginity as the honor of a family. Thus, such a brutal and cruel demarcation of masculine and feminine behaviors led to injustice in society.

In the most of Marquez's novels, some of the male characters were involved with prostitutes; for instance, in Love in the Time of Cholera, the main character, Florentino, had relationships with many women. Other novels also have prostitutes namely Pilar Ternara in One Hundred Years of Solitude and Maria Alejandrina Cervants in Chronicle of a Death Foretold. It implies that prostitution was a common phenomenon in Latin America, and having relationships with prostitutes was acceptable in the society. On the other hand, the married women had to prove their virginity on the wedding night, failing which caused them rejection from their families for ever.

Another significant fact is that women from the lower classes are easily vulnerable to sexual harassment by the upper class men. This is seen in Chronicle of a Death Foretold where the cook Victoria Guzman from the low class was seduced by Ibrahim Nasar while she working in his house as a cook as also her daughter Divina Flora. Her mother was so paranoid about her daughter not being seduced by Santiago Nasar that she did not even allow her daughter to enter to his room. Hence, she had a feeling of revenge from Santiago Nasar; even when she came to know that Vicario brothers had decided to kill him, she did not inform him about their decision, she gained satisfaction from the fact that Santiago Nasar was to be killed.

Actually, the violence against women in Latin America is clearly manifested in One Hundred Years of Solitude when a solider gives a report to Colonel Aurelino Buendia that the lady of a leading Spanish company passing through the capital has been kidnapped by a band of masked highwaymen and on the following Sunday she was forced to dance in the nude at the summer house of the president of republic (165). Marquez always criticizes the denial of women's rights and the misusing of them in society. Even in his novels, he has represented some of the female characters whose morality and dignity were more than the male characters as in One Hundred Years of Solitude where Ursula was shown managing the entire family of Buendia in a reasonable and responsible way. She was kept alive till the end of the novel. And in Love in the Time of Cholera, Fermina was represented as a dignified widow of Dr. Urbino, and also in No One Writes to the Colonel, the wife of the colonel tried to keep her husband's dignity when they were in an impoverished condition. Marquez also praised the beauty of women in some of his novels. In One Hundred Years of Solitude, Remedios becomes the beauty Queen, in Chronicle of a Death Foretold, Aberta Simons, Bayardo's mother, was introduced as the beauty Queen of her time. She has been considered as the most beautiful of the past two hundred years in the Antilles (32).

Another significant theme is the indifference demonstrated by both the moral and legal institutions - the Church and the State - towards the killing of Santiago Nasar. They pay little attention to Vicario brothers' pre-planned decision of revenge. Father Carmen Amador, who is the chief in charge of the social values of the town, refuses to get involved or take any necessary action to prevent the murder although his command would certainly have stopped the killing. However, he justifies his indifference by claiming to be busy in preparing for the imminent arrival of the Bishop who "arrives but does not disembark to greet the people who so anxiously await his visit. The civil authorities could stop the killing, but also choose to ignore it. The mayor of the town, Lazaro Aponte, could incarcerate the twins for carrying the knives and threatening to kill Santiago, but he chooses not to. It is his nonchalant way of enforcing the law that permits the twins to commit their crime" (Pelayo 2001: 126).

Therefore, the novel Chronicle of a Death Foretold gives a clear perspective about the cultural aspects of the Latin American society of the past, a society in which people were guided by prejudices, deceits and cheap sensuality. Social rules and conventions dictated by the court and religious authorities were strictly followed. Even after committing the murder of Santiago Nasar, the court never condemned Vicario brothers to life imprisonment, and they were never considered guilty in public and, thus, released after spending a short time in jail to continue their normal life. Marquez in fact criticized both the ruling system for its misrule and the religious authorities who ignored the issue of murder and performed an autopsy on Santiago Nasar's body which was actually the second butchery of Santiago Nasar because the local doctor had left the town because of the presence of the priest. Then, an investigation was started to discover the facts of the murder; the investigator spent five years in investigating the matter, uselessly wasting time in the tidewashed offices of the Ministry of Justice in Riohacha. At the end, he only provided a report with 322 pages without any clear result.

\section{Multi-Cultural Society}

From colonial times, Colombia's society comprised of a multi-cultural and racial ethnicity. Many people immigrated to Latin America from different parts of the world such as Africa, America, Europe and some from Arab countries as well. The majority of them were businessmen who settled in both central and South America. Some immigrants from Syria, Lebanon and Palestine moved to the Caribbean region in the latter part of the nineteenth century. They were mostly Christians fleeing from the Turkish persecution, initially working as wandering salesmen in the Caribbean region. In the 
recent times, their descendants have fully integrated into the social and political realms of a number of the Latin American countries. Marquez has always tried to portray these groups or communities in his novels as an alienated and unassimilated group. In One Hundred Years of Solitude, he refers to a 'street of the Turks' where Arabs carry out business such as exchange of trinkets for macaws. In No One Writes to the Colonel, the colonel's wife emphasizes by her remark that even she has gone to the Turks to sell her pictures.

In the novel Chronicle of a Death Foretold, Marquez has given a clear portrait of the social and cultural conditions of the Colombian community in which people of different races and cultures lived in peace, including Arabs who conducted business and brought many goods to sell in Macondo as it was manifested in One Hundred Years of Solitude. Also, in Chronicle of a Death Foretold, a group of Arabs was presented speaking Arabic among themselves. The father of Santiago Nasar, Ibrahim Nasar, was also one of catholic Arab businessmen who had immigrated there at the end of the civil wars. The society was permissive enough to allow Ibrahim Nasar to marry a local woman, Placido Linero and integrate into the community. His son, Santiago Nasar, however, married an Arab girl Flora Miguel who was also the daughter of an immigrant Arab. The Arab community was a peaceful immigrant community settled in the Caribbean towns at the beginning of the twentieth century. They were clannish and hard working and almost always married within the community. They were selling colored cloth and trinkets and also importing wheat and grew oregano and eggplant. But the murder of Santiago Nasar suddenly changed this peace into sadness and wailing.

\section{Preservation of Social Norms}

Another significant theme of Love in the Time of Cholera is the representation of Dr. Urbino as a caricature of Latin America, his house was full of original English furniture and French porcelain, his parrot spoke French and Latin and his books came from France, indicating that Dr. Urbino paid more attention to the literary fashions of France than to those of Spain. Although he was an internationally educated figure, he always wanted to retain to his traditional customs. He believed that the Latin American culture should be restored and separated from other foreign culture because it did not have any common point with any culture. Nevertheless, for a long time, the Latin American culture was a kind of imitation of other cultures. Marquez has always criticized it and emphasized the superiority of the Latin American cultural values that have been the distinguishing characteristics of large sections of the Latin American middle classes in the twentieth century. Like Dr. Urbino, Marquez himself has lived many years in many European countries and never forgot his origins, insisting on restoring his local culture. Because of this, he has always tried to represent the identification of Latin America as an outstanding value in his novels. He believed that Latin America was totally different from America and European countries. He was thus against the application of any foreign cultural or political models for solving the problems of the Latin American countries since he believed that these models were not fit for the socio-cultural aspects of this continent.

In the novel, there is an ironical relationship between Dr. Urbino's tendency towards modernism and Marquez's tendency to his native land. Because of this, Dr. Urbino is gradually undermined as the story progresses. In fact, his problem was that he could not adjust or apply his misplaced faith since he was unable to consider all aspects of his society. As a doctor, Dr. Urbino tried to apply his modern ideas in the town; he succeeded in establishing some civil services and health protection services for preventing the increase of diseases. The first achievement of Dr. Urbino was to establish a civil fire service centre. But it became the main factor of his death since after establishment of this centre, according to his experience in Europe, he thought that a firemen's responsibility was not only to put out fire, but also to rescue human beings or animals trapped or in trouble such as the rescuing of mountain climbers who has got buried in the avalanche or animals that fell into wells. However, it was natural for him to request help from the fire brigade to catch his parrot who had fled from the cage. The gap between conception and execution was large: the way he conceptualized the fire service and the way they behaved and performed their duty were far apart. They came to catch the parrot, but failed. Dr. Urbino himself fetched the ladder and tried to catch the parrot perched on the tree, but fell and died. It implies that, instead of having the effect of progression, modern ideas or plans have always had a devastating effect on the society of Latin America.

Dr. Urbino struggled a lot for the development of his society. After finishing his medical course in Paris, he came back to his home land to realize that his father, who was also a doctor, had died of cholera. In the nineteenth century, Europe also suffered from a great cholera epidemic which caused the death of many people. Whereas he was a specialized physician in bacteriology and educated under the training of the most famous European bacteriologists Dr. Luis Pasteur and Robert Koch, he decided to work against this disease in his native land. He started to transform the medical conditions with his modernizing zeal and attitude; for instance, the hospital he worked for was previously controlled or managed by dark superstitions; they put the legs of the patients in jars in order to prevent the spreading of disease. Dr. Urbino struggled against these ridiculous practices and skepticism. He brought a new water supplying system, an improved sewer system and others. When cholera appeared in the town, he also took effective and appropriate measures for averting it.

It is obvious that whatever he did was a scientific and moral accomplishment and they were admirable, but Marquez clearly highlighted the dangers of the application of the attitudes and ideas of Dr. Urbino. He felt that Dr. Urbino's ideas could not suit or fit to the realities of Latin America. Dr. Urbino himself came to the same conclusion. When he was abroad, he was very nostalgic for his native land. When he came back, he found that it was not worthy of his nostalgia: He found out that nothing had changed; the streets were full of rats and the poverty was eye catching. Although he did a lot of admirable work for the improvement of the town, the problems were more profound than they appeared; the town had fallen prey to poverty. His endeavors did not reach out to all the people, neither to their health problems. 
Eventually, he came to realize that his modernizing dream was condemned to failure; he said that "nineteenth century is passing for everybody, except us" (225). Although he had taken many preventive measures for controlling cholera, he could see from the balloon that people were dying not because of the cholera; rather it was poverty and civil wars that caused their death.

\section{Domination of Skeptical Rationalism}

In the novel Of Love and Other Demons, Marquez clearly portrays the social context of Colombia in the period of Colonialism. In this case, it is comparable with his other novels such as One Hundred Years of Solitude, The General in His Labyrinth and Chronicle of a Death Foretold, representing the social and cultural aspects and the historical events of his country and Latin America. In the novel Of Love and Other Demons, Marquez goes two hundred years back before Latin America got its independence from Spain, before the French Revolution and the Enlightenment and even before the dreams of the social revolution of 1917. Indeed, the novel refers to a world where no revolution seemed conceivable and any kind of Bolivarian idea was unimaginable.

The story of Of Love and Other Demons is basically a historical fiction mirroring the Hispanic-American system that prevailed in the period of colonialism. In fact, its main character, Sierva Maria, represents the multi-cultural situation of that period. The novel actually depicts a clash of different cultures such as Spanish, Christian and African in Latin America. This situation caused Sierva Maria to have a multi-cultural identity; her father had more Spanish identity and her mother an African one. Even her name implies her mixed cultural identity; her first name is Spanish and means 'Servant of God' her mother also selecting an African name for her. Sierva Maria was able to speak the African language and she was at the same time familiar with the African culture more than the Colombian one. Delaura, one of the characters, says that "what seems demonic to us are the customs of the blacks, learned by the girl as a sequence of the neglected condition in which her parents kept her" (97).

Therefore, the main beliefs of the people living near the Caribbean Sea were those of Catholicism because of the Spanish colonialism after which Spanish culture permeated every aspect of the Colombian culture. Actually, every person was made a catholic but filled with superstition. If anybody was not catholic, was in danger of being ostracized by society. The church and ruling system directly influenced each other; the church was more dominant in society, and even interfered in the social and private matters of the community. Another point is that the Spanish and African culture had created ignorance and dark superstition that filled the life of the people with useless fear of animals and of the animal nature of human beings and of unknown things. It was so rooted in the people's belief that a boy, Ygnacio, was afraid of all kinds of pets and harmless animals, even chickens. He imagined that it had "grown to the size of a cow and realized it was a monster more fearsome than any other on land or sea" (35). He says that "I live in fear of being alive" (35). He indeed suffers from hallucinations and says that all animals had left his estate "in a sinister line that disappeared into the night" (36), except hunting mastiffs, whom he had befriended. When a horse died, they believed that it should be buried on holy ground and Marquis, Sierva Maria's father, arranged for the burial. When a person died of rabies, the father Aquino, a severe priest, ordered that the carcass of a large sinister dog should be hung from a bridge so that "everyone would know it had died of rabies" (145). Indeed, the carcass of the dog gives a martyred sanctity and a kind of bliss. The story also actually describes the social condition of a town where a lot of slaves had been brought from African countries for sale and where people, Turkey buzzards, pigs and dogs lived with each other. In this kind of situation, it is obvious that Sierva Maria is victimized by the ignorance and superstitions and ridiculous attitudes of sanctity and demonic possession.

Despite the fact that rabies does not develop and her wound heals without leaving any trace, the Bishop thinks that Sierva Maria may be mad because of rabies and possessed by a demon. They impose on her a series of barbarous cures. The Catholic Church believes that "she is possessed by the devil - she has merely taken on African beliefs - and urges the Marquis (Maria's father) to have her exorcised. She is taken to convent of Santa Clara for supervision and the Bishop brings in one of the up-and-coming experts on possession and exorcism, Cayetano Delaura, a theologian and librarian destined, it is said, for the Vatican" (Martin 2008: 508). Cayetano who does not have any experience of how to behave with women, before meeting Sierva Maria, had dreamt about the girl who was in a room eating grapes from her lap that never run out; if they did she would die. He meets Sierva Maria in the convent, her hands and feet had been tied to the bed because of her rage. She is exactly the girl of whom he had dreamt and he knows that she is unable to tolerate their cruel treatment. He succeeds in meeting her secretly in the convent every night. Finally he declares his true feelings, embraces her, and they sleep together without quite completing the sexual act. After several months in the convent, they start to exorcise directly before the Bishop cutting Sierva Maria's hair and burning it. Cayetano's love for her becomes known and he is condemned to work in a hospital for lepers. She waits for him and refuses to eat because of his absence. In her turn, she dreams about the field of snow but now she eats the grapes two at a time in her fever to get to the last one. After the sixth exorcism, she dies and her shaven head bursting with hair in the grave.

In reality, the main person who had contributed to Sierva Maria's death was the Bishop himself. It was he who ordered that Sierva Maria be sent to the convent and he who had personally conducted the processes of exorcism on her although she had not shown any sign of rabies. She only had some other medical symptoms such as infected bites, the Bishop ignored them and insisted on his own belief about her illness. It implies that her death is unrelated to the dog biting her; the fact is that she died due to the superstition and dark mindset of the Bishop. He insisted on his dogmatic view that she was possessed by demons. In the novel, it is inferable that the Bishop himself had no faith in God, but always tried to intimidate the entire society by the powers of the Holy Office. The Bishop was not the only person who had demonic behavior, the nuns in the convent were also demons themselves. One of them was Abenucio who always 
pretended that she was a woman of faith. She bitterly blamed Sierva Maria with her religious jests, even labeled her as a demon.

\section{Conclusion}

Marquez's works actually portray the complicated history of his country and the continent with their critical events that caused the region to take away from its own local values and cultural beliefs and to be replaced by superstitions and dark beliefs that were indeed the legacy of colonialism. This in turn led the continent to lose its sovereignty and unity, and to be divided into small countries that were unable to establish well organized governments because of their dictatorial ruling systems. Due to the lack of proper local governance, the foreign powers developed their imperialistic domination in the region and it had a devastating effect on the daily life of population, resulting in violence, instability, insecurity and poverty. The beginning of the twentieth century, a period between pre-industrialization and modernity, was marked by a set of bloody civil wars. Because of this, repression, oppression and horror were a common sight in the real life of the people who had actually experienced both fascinating and terrifying conditions before and after the arrival of imperialism. Marquez's literary discourse fundamentally portrays these kinds of realities by working on the themes such as solitude, labyrinth, massacre, death, male-domination, kidnapping and superstition among many others.

\section{References}

Bell-Villada, G. H. (1983). "Building a Compass.” In: Bell-Villada, Gene H. (2006). Conversations with Gabriel Garcia Marquez. Jackson, US: University Press of Mississippi. pp. 133-140.

Bell-Villada, G. H. (2009). Garcia Marquez: The Man and His Work. Second Edition. Chapel Hill: University of North Carolina Press.

Dryfus, C. (1983). “Playboy Interview: Gabriel Garcia Marquez.” Playboy, February, volume 3, pp. 65-77.

Dryfus, C. (1983b). "Playboy Interview: Gabriel Garcia Marquez.” In: Bell-Villada, Gene H. (2006). Conversations with Gabriel Garcia Marquez. Jackson US: University Press of Mississippi. pp. 96-132.

Gullon, R. (1971). "Gabriel Garcia Marquez and the Lost Art of Storytelling.” In: McMurray, George (1987). Critical Essays on Gabriel Garcia Marquez. Boston: G.K. Hall and Co. pp.129-139.

Hamill, P. (1988). “Love and Solitude.” (Interview with Gabriel Garcia Marquez). Vanity Fair, March, pp. $124-131$.

Janes, R. (1981). Gabriel Garcia Marquez: Revolutions in Wonderland. Missouri, Colombia: University of Missouri Press.

Janes, R. (1981). Gabriel Garcia Marquez: Revolutions in Wonderland. Missouri, Colombia: University of Missouri Press.

Marquez, G. G. (1981). “The Art of Fiction.” (The Paris Review Interviews II). In: Gourevitch, Phillip (2007). Gabriel Garcia Marquez: The Art of Fiction. New York: Picador. pp. 178-206.

Martin, G. (2008). Gabriel Garcia Marquez: A Life. London: Bloomsbury Publishing Plc.

Martin, G. (2008). Gabriel Garcia Marquez: A Life. London: Bloomsbury Publishing Plc.

McMurray, G. R. (1977). Gabriel Garcia Marquez. New York: Frederick Ungar Publishing Co.

Minta, S. (1987). Gabriel Garcia Marquez: Writer of Colombia. London: Jonathan Cape.

Pelayo, R. (2001). Gabriel Garcia Marquez: A Critical Companion. Westport: Greenwood Press

Pelayo, R. (2001). Gabriel Garcia Marquez: A Critical Companion. Westport: Greenwood Press.

Rodriguez-Vergara, I. (1998a). "Introduction: Critical Essays on the Work of Garcia Marquez." Trans. Anna Serra. Washington, DC: Organization of American States, no. 64, pp.2-6.

Samper, Maria E. (1989). “An Interview with Gabriel Garcia Marquez.” Semana, volume 14, pp. 27-33.

Simons, M. (1982). “A Talk with Gabriel Garcia Marquez.” New York Times, December 5, Late City Final Edition, Section 7, Page 7, Column 1.

Simons, M. (1988). “Gabriel Garcia Marquez on Love, Plagues and Politics.” In: Bell-Villada, Gene H. (2006). Conversations with Gabriel Garcia Marquez. Jackson, US: University Press of Mississippi. pp. 154-162.

\section{Internet Sources}

- $\quad$ Miller, M. \& Perry, J. (2009). Love in the Time of Cholera. SparkNote . Retrieved December 28, 2009. http://www.sparknotes.com/lit/cholera/themes.html

- $\quad$ Millner, Caille (2001).One Hundred Years of Solitude Study Guide. GradeSaver. Retrieved 16 December 2001. http://www.gradesaver.com/one-hundred-years-of-solitude/study-guide/section8/ 